\title{
A modeling framework to assess the impact of climate change on river runoff
}

\author{
Leszek Kuchar, Sławomir Iwański \\ Wrocław University of Environmental and Life Science, Department of Mathematics, Grunwaldzka Street 53, 50-357 \\ Wrocław, Poland, e-mail: Leszek.Kuchar@gmail.com \\ Leszek Jelonek, Wiwiana Szalińska \\ Institute of Meteorology and Water Management - National Research Institute, Parkowa Street 30, 51-616 Wrocław, \\ Poland
}

\begin{abstract}
Global climate change is anticipated to have consequences on water resources and the envi-ronment both at global and local/regional levels. Efforts towards proper management of future water resources and resolving potential water-related conflicts require the formulation of appropriate techniques to downscale the output of global climate models (GCM) to local conditions for hydrologic prediction. The paper presents an integrated framework for modeling the impact of climate change on river runoff that combines methodology for downscaling climate change scenarios for a basin scale with a hydrological model to estimate the impact of climate change on a river runoff. The modeling framework uses long-term observations of meteorological and hydrological variables together with a climate change scenario to provide a projection of future flows for the specified time horizon. The framework is based on a spatial weather generator and a distributed rainfall-runoff model. Such a configuration enables a reflection of the uncertainty of future conditions by running multiple realizations of future conditions, and also take into account the spatial variability of hydrological properties in the catchment by maintaining the physical details at a given grid size. The performance of the framework was presented for the Kaczawa basin that is one of the main left bank tributaries of the Odra River - the second biggest river in Poland. The results show simulated changes of the future river flow regime caused by climatic changes for two time horizons: 2040 and 2080.
\end{abstract}

Keywords: climate change, spatial weather generator, regional hydrology, distributed rainfall-runoff model

Submitted 10 April 2014, revised 13 January 2015, accepted 13 January 2015

\section{Introduction}

Projected changes in climate may have a potentially significant impact on the hydrological cycle and water resources (Barnett et al. 2004; Huntington 2006; IPCC 2007; Kundzewicz et al. 2007; Sivakumar 2011). There have been many studies that have focused on hydrologic modeling of the effect of climate change in different regions and scales (e.g. Müller-Wohlfeil et al. 2000; Bergstrom et al. 2001; Burlando, Rosso 2002; Chiew, McMahon 2002; Menzel, Bürger 2002; Arnell 2003; Christensen et al. 2004; Wood et al. 2004; Dibike, Coulibaly 2005; Merritt et al. 2006; Kilsby et al. 2007b; Leander, Buishand 2007; Caron et al. 2008; Bavay et al. 2009; Manning et al. 2009; Hagg et al. 2010; Grillakis et al. 2011; Vansteenkiste et al. 2012; Shrestha et al. 2012).

Assessing the impact of climate change on stream discharge puts high requirements on policy makers to respond to and mitigate the effects of potential changes. Evaluation of the hydrological impact of climate change is most commonly based on driving a hydrological model with climatic projections derived from general circulation models (GCMs) forced with alternative emission scenarios. The challenge is to downscale coarse spatial and temporal resolution of climate system simulations so as to reproduce short-term weather patterns and capture fine-scale atmospheric structures needed to drive a hydrological model. Various techniques have been developed to convert the large-scale outputs from the climate model into local meteorological variables that fall within two general categories: regional, high-resolution climate models (RCMs) and statistical downscaling techniques. RCMs are a promising approach, though the shortcomings, such as bias problems inherent to the parent GCM, calculation costs, simulations of extreme precipitation or obtaining consistent estimations on the local and site-specific scale still limit their hydrological use (Varis et al. 2004; Chen 
et al. 2011; Sharma et al. 2011). Developed in parallel to RCMs, statistical downscaling methods have been used to overcome these challenges. Weather Generators (WG) fall into the category of statistical downscaling techniques. WGs enable climate change impact assessments to be conducted at greater resolution in space and time than regional climate models (RCMs) allow, and are particularly relevant to studies in which the sequence of events is important, such as water resource provision (Wilks, Wilby 1999; Jones et al. 2009). WGs create a distribution of plausible estimates of a particular weather climatic parameter. With the use of them, it is possible to rapidly produce sets of climate data for studying impacts of rare climate events and investigating natural variability (Kilsby et al. 2007b; Qian et al. 2010; Wilks 2010, Chen et al. 2011, Fatichi et al. 2011).

There are two major sources of uncertainty in the assessment of the hydrological impact of climate change: uncertainties in the future greenhouse emission scenarios, and uncertainties in representing rainfall-runoff processes. One of the common approaches in investigating GCM uncertainty is to use a range of projections for the same emission scenarios derived from an ensemble of GCM (Sengupta, Boyle 1997; Thompson et al. 2013). Uncertainty in hydrological modeling can be reduced by attempting to use physically-based fully distributed hydrologic rainfall-runoff models. Ludwig et al. (2009) concluded that models with a low physical complexity are inadequate for application in a climate change context. While recently conceptual models were widely used in climate change impact studies (Dibike, Coulibaly 2007), nowadays distributed hydrological models have started to be applied for examining hydrological responses to climate change (Maurer et al. 2010). For example, the recently distributed rainfall-runoff model MIKE SHE was applied to study the hydrological impact of climate change for a different region (van Roosmalen et al. 2009; Sultana, Coulibaly 2010; Thompson 2012; Vansteenkiste et al. 2012; Thompson 2013). Fully distributed rainfallrunoff models maintain physical details at a given grid size and consider the distributed nature of hydrological properties such as soil type, slope and land use. Therefore, these more detailed physically based and spatially distributed models are assumed to give a detailed and potentially more correct description of the hydrological processes in the catchment and might therefore provide more accurate projections (Vansteenkiste et al. 2012).
This paper presents an approach to assessing the impact of climate change on a river runoff that combines the weather generator with the distributed rainfall-runoff model. In this approach a Spatial Weather GENerator (SWGEN) model was applied to downscale GCM projections, while future stream flows were modeled with the distributed MIKE-SHE rainfall-runoff model a Spatial Weather GENerator (SWGEN) was applied to downscale GCM projections, while future stream flows were modeled with the distributed MIKE-SHE rainfall-runoff model This configuration aims at reducing the uncertainty of future conditions by using a collection of GCM projections derived from the same emission scenario, running multiple realizations of future conditions with the weather generator and accounting for spatial variability of hydrological properties in the catchment by maintaining the physical details at a given grid size.

The performance of the modeling framework was presented for the Kaczawa basin, one of the main left bank tributaries of the Odra River - the second biggest river in Poland. The period 1981-2000 was analyzed as the baseline climate conditions for reference in assessing future changes. The presented results show simulated changes of a future river flow regime caused by climatic changes for two time horizons: 2040 and 2080. The time horizons represented the projected conditions in the respective periods under the assumption of the given emission scenario. The results from three GCM models were used to impose projected climate changes.

\section{Materials and methods}

The modeling framework to assess the impact of climate change on a river runoff is performed according to a scheme summarized in Fig. 1. The framework requires a collection of GCM model results, long term datasets of observed daily meteorological and hydrological conditions during the period of reference, and also spatial catchment characteristics. Observed meteorological and hydrological conditions are applied for calibration of the hydrological rainfall-runoff model. For the investigated emission scenario, projections from different GCM models are collected in order to provide future deviations from actual conditions for the specified time horizon. Calibration of the spatial weather generator is done by estimating spatiotemporal relationships among the analyzed variables from datasets of observed meteo- 


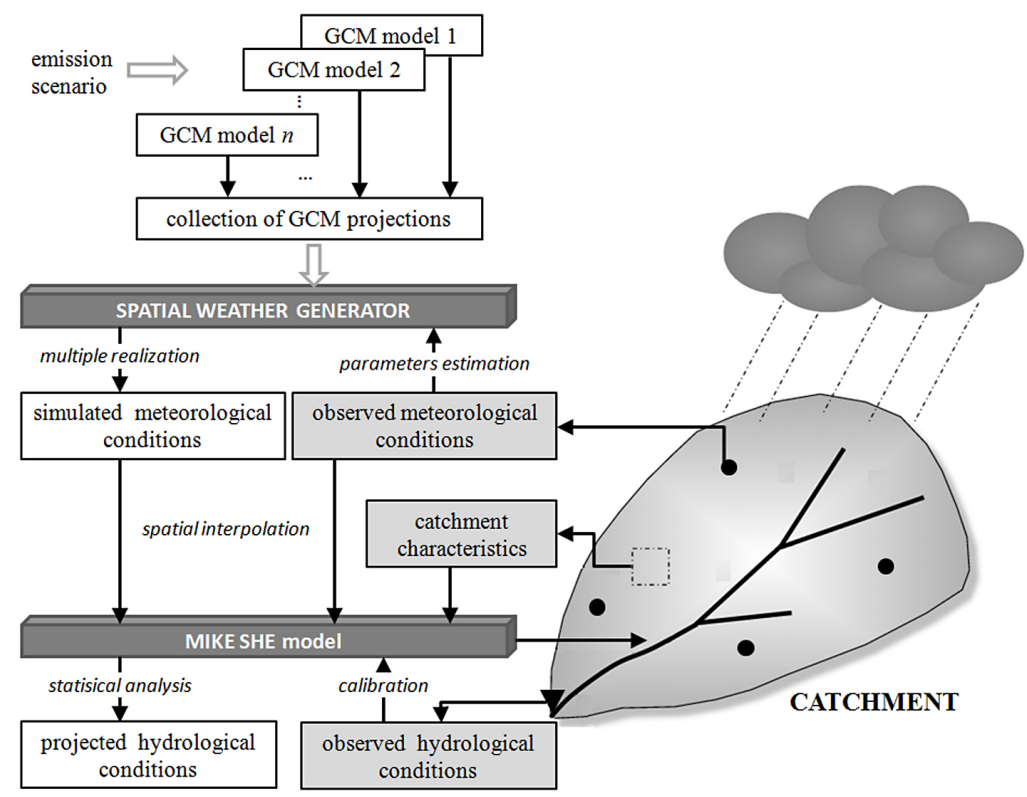

Fig. 1. Scheme of integrated modeling framework for hydrological assessment of climate change

rological variables. A multiple realization of baseline daily meteorological conditions is obtained with the use of a spatial weather generator. Developed characteristics of meteorological parameters for the baseline period are then modified according to the deviation coefficients adopted from GCM projections. Modified meteorological characteristics are then used to reproduce multiple sets of realizations of future daily meteorological conditions for the investigated time horizons. A calibrated rainfall-runoff model is then forced with the set of multiple realizations of baseline meteorological conditions and multiple realizations of future meteorological conditions in order to provide present and future runoff simulations. A set of multiple runoff simulations is compiled statistically to facilitate the assessment of the consequences of climate change on runoff regime.

This section presents tools and methods that compose a modeling framework to assess the impact of climate change on a river runoff, along with the data and materials used in the study to run the framework. The structure of the modeling framework consists of two tools: a weather generator and a hydrological rainfall runoff model. The methods that needed to be developed to provide the assumed framework functionality encompassed: weather generator calibration and validation procedure, hydrological model calibration and validation procedure; downscaling GCM projections with the use of the weather generator, climate change hydrological impact assessment by forcing the hydrological model with the data representing present and future conditions.

\subsection{Spatial Weather Generation model SWGEN}

Weather generators are more and more often used in a variety of water resource studies due to their ability to provide series of weather data for any length of time with similar statistics as observations to which the weather generators have been fitted (Khalili et al. 2009). The Richardson weather generator (WGEN) (Richardson, Wright 1984; Richardson 1985) is the most commonly used weather generator, and uses a first-order two-state Markov chain model to generate precipitation occurrences and distribution function, such as gamma or exponential, to model precipitation amounts. The next phase includes the generation of non-precipitation variables (maximum temperature, minimum temperature and solar radiation) by a continuous multivariate stochastic process, with daily means and standard deviation conditions on the wet or dry state of the day. Classic weather generators operate at a single site, and thus fail to reproduce the spatial dependence present in the observed data (Khalili et al. 2009). There have been several efforts to develop multi-site weather generators for precipitation data generation (Bardossy, Plate 1992; Bogardi et al. 1993; Hughes, Guttorp 1994; Wilks 1998; Hughes et al. 1999; Bellone et al. 2000; Brissette et al. 2007; Khalili et al. 2007; Tae-woong et al. 2007; Kilsby et al. 2007a). Multi-site generation of precipitation and non-precipitation data were developed by Wilks (1999) and Buishand and Brandsma (2001), Beersma and Buishand (2003), Khalili et al. (2009) and most recently by Chen et al. (2014). 
Applied Spatial Weather GENarator model (SWGEN) is based on a point WGEN model with modifications introduced by Kuchar (2004) and with extension to a spatial domain (Iwański, Kuchar 2003). The developed approach adopts the Richardson weather generator, and uses the spatial autocorrelation concept to reproduce the spatial dependence on observations based on the methods proposed by Buishand and Brandsma (2001) and Beersma and Buishand (2003). The SWGEN model uses historical datasets of daily measurements in order to estimate temporal variability and persistence of each variable along with inter-station correlation among the variables. SWGEN applies nonparametric methods to estimate parameters governing multi-site simulations of meteorological variables for individual months simultaneously for all collocated stations within the area of interest. The SWGEN model provides synthetic daily values for precipitation $(P)$, insolation $(I S)$, maximum temperature $\left(t_{\max }\right)$, minimum temperature $\left(t_{\text {min }}\right)$, and solar radiation $(S R)$.

\subsection{Hydrological rainfall-runoff model}

MIKE SHE is a spatially distributed, physically based, hydrologic model (Abbott et al. 1986). MIKE SHE simulates the terrestrial water cycle, including evapotranspiration, surface flow, unsaturated soil water, and groundwater movement. Evapotranspiration is modelled as a function of potential evapotranspiration, leaf area index, and root depth for each vegetation type using the Kristensen and Jensen (1975) method. Surface flow is described using a diffusive wave approximation of the Saint-Venant equations. Movement of water in unsaturated zones is assumed to be vertical. Unsaturated soil water infiltration and redistribution processes can be modelled using ichard's equation, the gravity flow method, or a simple soil water balance equation. Saturated water flow (i.e. groundwater) can be simulated by a linear reservoir or a 3D groundwater flow model. Detailed descriptions of the modelling procedures and mathematical formulation can be found in user's manual (DHI 2007) and associated publications (Feyen et al. 2000; Graham, Butts 2005; Sahoo et al. 2006).

\subsection{Weather Generator parameter estimation and validation}

The SWGEN model calibration procedure involves an estimation of model parameters from his- torical data sets. Model parameters were estimated from the daily data sets of analyzed meteorological parameters: $S R$ (solar radiation), $t_{\min }$ and $t_{\max }$ (minimum and maximum temperature) and $P$ (precipitation total) obtained for each station location within the analyzed catchment. The characteristics of each analyzed meteorological parameter are represented through monthly mean value and standard deviation. For the stations with a lack of measurements of a given meteorological parameter, these characteristics were obtained with the use of interpolation techniques: ordinary kriging or the inverse distance weighing method. The selection of better interpolation techniques is performed with the use of the crossvalidation method while applying criteria based on the value of root mean square error.

In the next phase, observed daily precipitation time series are used to calculate transition probabilities of wet/dry days and to estimate parameters of gamma distributions for each station and each month. Following this, daily mean, maximum and minimum temperatures, together with total solar radiation data sets are applied to estimate the parameters of the covariance matrix describing temporal and spatial interdependencies among these variables.

The set of estimated statistical parameters are then used to generate stochastically realistic climate data corresponding to current conditions. The validation procedure involves assessment of the quality of reproduction of the statistical properties of the observed datasets from the simulations obtained from the parametrized SWGEN model.

\subsection{Rainfall-runoff model calibration and valida- tion}

To model the total runoff from Kaczawa catchment, the study area was represented as the integrated system of subcatchments connected with each other. Subcatchments were modeled with the use of a rainfall-runoff MIKE SHE model while connections were modeled by a 1D hydrodynamic MIKE 11 model. Delimitation of the subcatchments area was done on the basis of physiographic catchment characteristics and the locations of the monitoring stations. Sections of the 1D hydrodynamic model represented the existing river network.

The model, consisting of the subcatchments and connecting river segments, was calibrated in two phases. The first phase included initial calibration of the river system model 1D (one-dimensional hy- 
drodynamic model). The purpose of the calibration was preliminary verification of model stability and estimation of the time it would take a flood wave to move along the channels. This was done with the use of hydrological data - observed discharge at the river Kaczawa gauging stations and its major tributaries. In total, data from 4 gauging station in the river Kaczawa and 5 located on the main tributaries was chosen. Calibration was performed for the selected flood episodes. The second phase included calibration of the set of parameters that have a direct impact on the process of runoff from the catchment. Calibration of the model parameters was done with the use of hydrological observations at the stream gauges located at the tributaries of Kaczawa and for the Piątnica water gauge station that closes the research area.

The topography of the catchment area was described by a digital terrain model with horizontal resolution of $1 \mathrm{~km} \times 1 \mathrm{~km}$, covering the entire Kaczawa catchment. Slope calculations were the basis for the assessment of surface runoff in each catchment. The applied snow melt procedure is a degreeday method where the rate of melting depends on the increases in air temperature. The evapotranspiration model was used in the Two-Layer UZ/ET structure which divides the unsaturated zone into a root zone, from which ET can occur, and a zone below the root zone, where ET does not occur. The calculation of evapotranspiration uses meteorological and vegetative data to estimate the total evapotranspiration and net rainfall. Net rainfall is the rainfall reduced by the evaporation from the soil surface and interception.

For each subcatchment the saturated zone was represented by a series of interdependent, reservoirs: upper reservoirs, interflow reservoir and a number of separate, lower groundwater reservoirs that produce a baseflow. The ground water flow from the saturated zone was estimated with the use of the linear reservoir method.

Calibration was undertaken using the time constants of the saturated zone linear reservoirs, the dead storage proportion for the lower baseflow reservoirs, and, in sub-catchments with a wide elevation range, precipitation lapse rate. Two equally weighted calibration criteria, the absolute value of the average error and the root mean square error, were employed (Butts et al. 2004). Model performance at each gauging station was assessed using the Nash-Sutcliffe coefficient (NSE; Nash, Sutcliffe 1970), the Pearson correlation coefficient ( $\mathrm{r}$ ) and the percentage of rootmean-square error (RMSE).

\subsection{Study area and hydro-climatic data}

The Odra River is the second biggest river in Poland. The upper region of the Odra river basin (SW Poland) faces considerable flood hazards associated with extreme rainfall and melting snow, especially in the Sudeten Mountains (Szalińska et al. 2014). The left tributaries drain the mountainous region exposed to high precipitation and may temporarily show considerable discharges resulting in flood danger in the lowland areas. The Kaczawa catchment is one of the major left tributaries of the Odra, located at Sudeten foothills. Its catchment area is $1807 \mathrm{~km}^{2}$. Due to its location, the Kaczawa catchment has very differentiated landscape, with a specific climate typical for mountain and mountain-foot regions. The average annual air temperature is lower than $7^{\circ} \mathrm{C}$. The average annual precipitation varies from 500 to $800 \mathrm{~mm}$. Snow cover remains for about 40-45 days a year. Small post-glacial lakes, three dry reservoirs used for flood protection and one multipurpose reservoir with total capacity of $41 \mathrm{mln} \mathrm{m}^{3}$ are located in the Kaczawa catchment. At the final water gauge - Piąnica, the maximum discharge $\left(418 \mathrm{~m}^{3} / \mathrm{s}\right)$ was recorded in July 1997.

Meteorological parameters that are required for the integrated modeling framework are: long term datasets of precipitation $(P)$, solar radiation $(S R)$, insolation (IS), temperature $(t)$. These variables were obtained for the Kaczawa catchment from monitoring stations operated by the Institute of Meteorology and Water Management - National Research Institute. Measurements from stations located within the study catchment (16 meteorological stations) and in the catchment vicinity ( 8 meteorological stations) were provided for the period 1981-2000 (Fig. 2). The

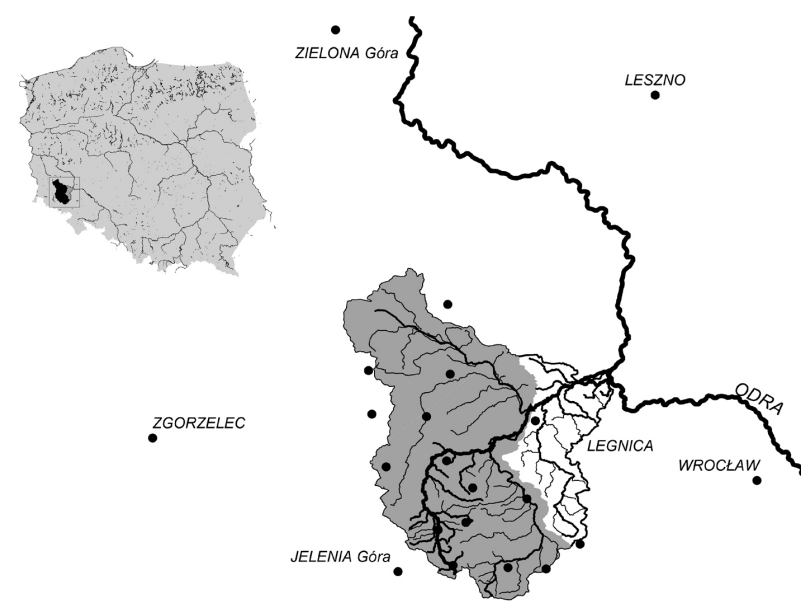

Fig. 2. The Kaczawa River catchment and location of weather stations used in the study 
choice of available measured meteorological parameters differed among stations (Tab. 1). For the stations with insolation measurements, solar radiation values were obtained with the Black formula (Black et al. 1954).

Table 1. Weather stations and measurements used in the study $(P$ - precipitation, $S R$ - solar radiation, $I S$ - insolation, $t$ - temperature)

\begin{tabular}{|c|c|c|c|c|c|}
\hline \multirow{2}{*}{ No } & \multirow{2}{*}{ Station } & \multicolumn{3}{|c|}{ Location } & \multirow{2}{*}{ Data } \\
\hline & & Long. & Lat. & Alt. & \\
\hline 1. & Bolków & $16^{\circ} 06^{\prime} \mathrm{E}$ & $50^{\circ} 55^{\prime} \mathrm{N}$ & 361 & $P$ \\
\hline 2. & Chocianów & $15^{\circ} 55^{\prime} \mathrm{E}$ & $51^{\circ} 25^{\prime} \mathrm{N}$ & 146 & $P$ \\
\hline 3. & Chojnów & $15^{\circ} 56^{\prime} \mathrm{E}$ & $51^{\circ} 17^{\prime} \mathrm{N}$ & 162 & $P$ \\
\hline 4. & Dobromierz & $16^{\circ} 15^{\prime} \mathrm{E}$ & $50^{\circ} 55^{\prime} \mathrm{N}$ & 278 & $P$ \\
\hline 5. & Iwiny & $15^{\circ} 42^{\prime} \mathrm{E}$ & $51^{\circ} 12^{\prime} \mathrm{N}$ & 211 & $P$ \\
\hline 6. & Jawor & $16^{\circ} 11^{\prime} \mathrm{E}$ & $51^{\circ} 03^{\prime} \mathrm{N}$ & 178 & $P$ \\
\hline 7. & Kaczorów & $15^{\circ} 58^{\prime} \mathrm{E}$ & $50^{\circ} 55^{\prime} \mathrm{N}$ & 487 & $P$ \\
\hline 8. & Legnica & $16^{\circ} 12^{\prime} \mathrm{E}$ & $51^{\circ} 12^{\prime} \mathrm{N}$ & 107 & $\begin{array}{l}S R, I S, \\
t, P\end{array}$ \\
\hline 9. & Lubin & $16^{\circ} 12^{\prime} \mathrm{E}$ & $51^{\circ} 24^{\prime} \mathrm{N}$ & 127 & $P$ \\
\hline 10. & Stanisławów & $16^{\circ} 01^{\prime} \mathrm{E}$ & $51^{\circ} 04^{\prime} \mathrm{N}$ & 373 & $P$ \\
\hline 11. & Strzegom & $16^{\circ} 21^{\prime} \mathrm{E}$ & $50^{\circ} 58^{\prime} \mathrm{N}$ & 227 & $P$ \\
\hline 12. & $\begin{array}{l}\text { Tomaszów } \\
\text { Bolesławiecki }\end{array}$ & $15^{\circ} 41^{\prime} \mathrm{E}$ & $51^{\circ} 17^{\prime} \mathrm{N}$ & 186 & $t, P$ \\
\hline 13. & Twardocice & $15^{\circ} 45^{\prime} \mathrm{E}$ & $51^{\circ} 06^{\prime} \mathrm{N}$ & 258 & $P$ \\
\hline 14. & $\begin{array}{l}\text { Wojcieszów } \\
\text { Dolny }\end{array}$ & $15^{\circ} 55^{\prime} \mathrm{E}$ & $50^{\circ} 59^{\prime} \mathrm{N}$ & 397 & $P$ \\
\hline 15. & Zagrodno & $15^{\circ} 52^{\prime} \mathrm{E}$ & $51^{\circ} 12^{\prime} \mathrm{N}$ & 193 & $P$ \\
\hline 16. & Złotoryja & $15^{\circ} 56^{\prime} \mathrm{E}$ & $51^{\circ} 07^{\prime} \mathrm{N}$ & 223 & $P$ \\
\hline 17. & Chwałkowie & $16^{\circ} 37^{\prime} \mathrm{E}$ & $51^{\circ} 27^{\prime} \mathrm{N}$ & 159 & $t$ \\
\hline 18. & Jelenia Góra & $15^{\circ} 48^{\prime} \mathrm{E}$ & $50^{\circ} 54^{\prime} \mathrm{N}$ & 345 & $I S, t$ \\
\hline 19. & Leszno & $16^{\circ} 32^{\prime} \mathrm{E}$ & $51^{\circ} 50^{\prime} \mathrm{N}$ & 87 & $I S, t$ \\
\hline 20. & $\begin{array}{l}\text { Polkowice } \\
\text { Dolne }\end{array}$ & $16^{\circ} 03^{\prime} \mathrm{E}$ & $51^{\circ} 30^{\prime} \mathrm{N}$ & 150 & $t$ \\
\hline 21. & Pszenno & $16^{\circ} 33^{\prime} \mathrm{E}$ & $50^{\circ} 51^{\prime} \mathrm{N}$ & 205 & $t$ \\
\hline 22. & Wrocław & $16^{\circ} 53^{\prime} \mathrm{E}$ & $51^{\circ} 06^{\prime} \mathrm{N}$ & 110 & $I S, t$ \\
\hline 23. & Zgorzelec & $15^{\circ} 02^{\prime} \mathrm{E}$ & $51^{\circ} 08^{\prime} \mathrm{N}$ & 198 & $t$ \\
\hline 24. & Zielona Góra & $15^{\circ} 32^{\prime} \mathrm{E}$ & $51^{\circ} 56^{\prime} \mathrm{N}$ & 169 & $I S, t$ \\
\hline
\end{tabular}

\subsection{Downscaling projections of climate change}

Downscaled climate changes are simulated by adjusting the parameters of the weather generators in a manner consistent with simulations obtained from Global Circulation Models (GCM). GCM are mathematical representations of numerous atmospheric, ocean and land surface processes based on the laws of physics. Such models consider a wide range of physical processes that characterize the climate system and have been used to examine the impact of increased greenhouse gas concentrations on the global climate (Gates et al. 1985). The approved set of emission scenarios is described in the IPCC Special Report on Emission Scenarios (SRES) (Nakicenovic et al. 2000). Adjustment of the SWGEN parameters is achieved by forcing changes in the values of monthly statistics for precipitation and temperature. The basic foundation for adapting weather generators for future climate projection is the assumption that statistical relationships between climatic parameters nowadays will remain constant in the future. Another assumption stems from the fact that the analyzed climate change scenarios do not specify changes in the solar radiation behavior and therefore these characteristics are assumed to remain unchanged. The procedure for obtaining downscaled projections of climate change for the catchment scale is done by generating multiple realizations of future meteorological conditions individually for each month for the set of collocated stations within the catchment area.

\subsection{Climate change hydrological impact assess- ment}

The hydrological impact of climate change is assessed by a comparative study of probability distribution functions $(P D F)$ developed for present and future runoff conditions. This is achieved by applying the SWGEN model to generate multiple realizations of present and future meteorological conditions. Each realization of 1 year of daily time series of meteorological conditions $\left(P, t_{\min }, t_{\max }, S R, I S\right)$ is introduced to the calibrated hydrological model MIKE SHE and the resulting 1 year of mean daily discharge values in a catchment's final water gauge is obtained. This procedure is repeated for a number of replicated time series (present and future). From the resulting multiple hydrograph realizations, the empirical pro-babilities of the given values are calculated. The distribution that best fits river discharge probability distributions is selected based on K-S and Chi-Square tests. Fitting results to $P D F \mathrm{~S}$ allows the reduction of the uncertainty of daily time series of each variable and also for the examination of general tendencies for river runoff. Information on statistical properties of the obtained $P D F \mathrm{~s}$ was the basis for inferring climate change impacts on river runoff. There is no upper limit for the number of replications obtained with the use of the SWGEN model, although from the authors' experience, a number of around 300-500 replications allowed for better selection of statistical distribution that best fits the produced hydrological data sets. 
The applied procedure, which relies on the use of synthetic data generated from SWGEN for both present and future conditions to model hydrological response, was to mitigate the uncertainty introduced by the hydrological model. Otherwise, in cases of comparison of the present runoff measured conditions with the ones obtained from the hydrological model, comparison results would be affected by the model performance.

\section{Results}

The performance of a developed modeling framework to assess the impact of climate change on a river runoff was presented for the study of the Kaczawa catchment. Investigations were done for the value of maximum daily discharge within different periods of time: year, season or month. As the baseline conditions, year 2000 was chosen (according to reference period: 1990-2010). The impact of climate change was investigated for the A1B scenario with the results obtained from three different GCM models for the time horizon 2040 and 2080. The climate projections were downscaled, with the use of the SWGEN model, to the spatio-temporal resolution required for the distributed rainfall-runoff model MIKE SHE.

\subsection{Climate change projections for the catchment scale}

- Within the study, scenario A1B was investigated. The scenario assumes a balance across all sources of energy for a future world of very rapid econo-
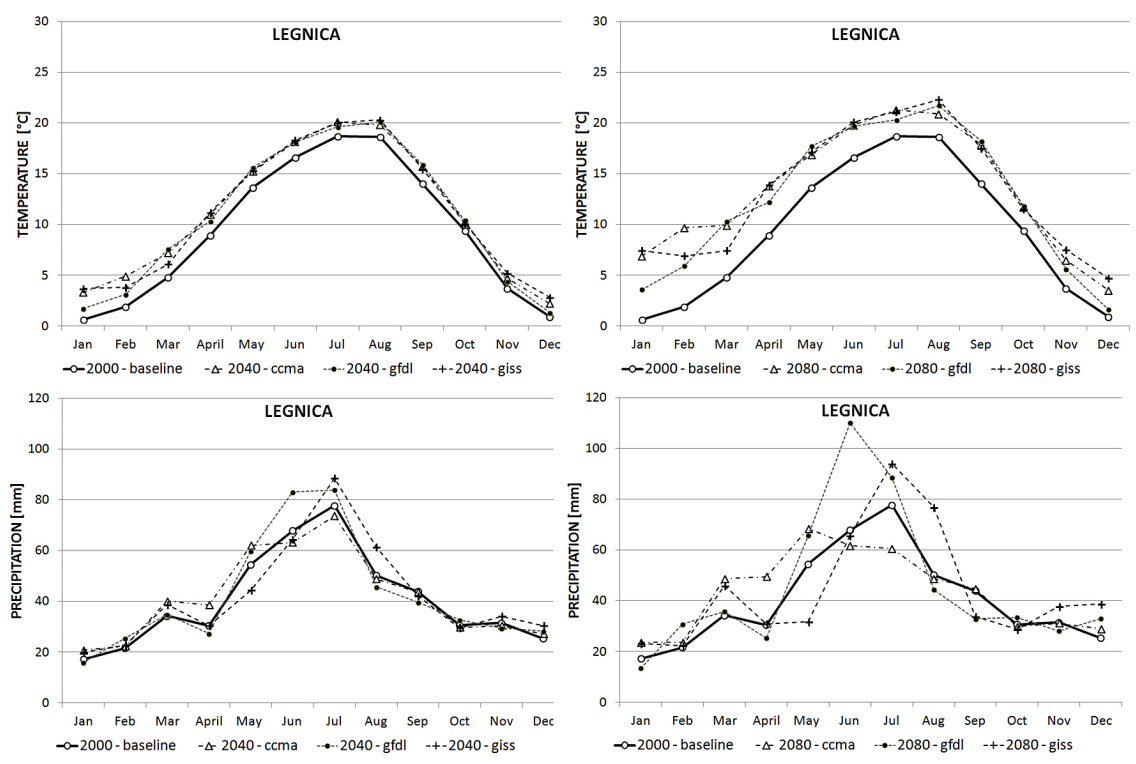

Fig. 3. Estimated impact of climate change on mean temperature (upper panel) and precipitation (lower panel) patterns in Legnica for the present and future periods mic growth, a global population that peaks in the mid-century and declines thereafter, and the rapid introduction of new and more efficient technologies (IPCC-SRES-SPM 2000; Nakicenovic et al. 2000). Three GCM models were used to develop climate change projections within the investigated area: GISS-ER model developed by NASA's Goddard Institute for Space Studies (GISS), USA. - GFDL-CM2.0 model developed by the Geophysical Fluid Dynamics Laboratory (GFDL), USA.

- CGCM 3.1 (Coupled Global Climate Model) developed by the Canadian Centre for Climate Modeling and Analysis (CCCma), Canada.

Tables 2 and 3 summarize the estimations of projected deviations from present conditions for the area of the Southwest part of Poland according to selected GCM models obtained with the use of MAGICC/ SCENGEN 5.3 software (Wigley 2008). The 5.3 version of the software is consistent with the IPCC Fourth Assessment Report, Working Group 1 (AR4).

The values representing climate change projection for the area of SW of Poland were used to modify the climatological characteristics for each location within the Kaczawa catchment. Fig. 3 shows the projected impact of climate change on climatological pattern of temperature and precipitation in Legnica, developed for different GCM models and time horizons. In contrast to temperature, there was a wide variation in the magnitude and direction of the projected changes in precipitation between investigated GCMs, particularly for the longer time horizon (2080). The biggest increase in precipitation for the summer period was attributed by the GFDL model, with the shift in the occurrence of 
Table 2. Assumed changes of climate elements for the time horizon 2040 according to adopted GCM models for the analyzed area

\begin{tabular}{|c|c|c|c|c|c|c|c|c|c|c|c|c|c|c|}
\hline \multirow{2}{*}{$\begin{array}{l}\text { GCM } \\
\text { model }\end{array}$} & \multirow{2}{*}{ par. } & \multirow{2}{*}{ stat. char. } & \multicolumn{12}{|c|}{ Climate projections for 2040} \\
\hline & & & Dec & Jan & Feb & Mar & April & May & June & July & Aug & Sept & Oct & Nov \\
\hline \multirow{8}{*}{ 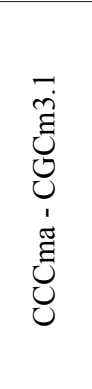 } & \multirow{4}{*}{$T$} & \multirow{2}{*}{ mean $\left[{ }^{\circ} \mathbf{C}\right]$} & 1.8 & 3.4 & 3.9 & 3.2 & 2.7 & 1.9 & 2.0 & 1.8 & 1.3 & 2.2 & 1.1 & 1.3 \\
\hline & & & \multicolumn{12}{|c|}{2.2} \\
\hline & & \multirow{2}{*}{ std [\%] } & 9.7 & -41.9 & -61.0 & 35.0 & 83.5 & -48.3 & -23.8 & -81.5 & 29.2 & 22.2 & -6.1 & -91.1 \\
\hline & & & \multicolumn{12}{|c|}{-24.7} \\
\hline & \multirow{4}{*}{$P$} & \multirow{2}{*}{ mean $[\%]$} & 11.1 & 22.0 & 0.7 & 22.2 & 31.0 & 13.5 & -6.9 & -6.4 & -1.0 & 1.4 & -1.7 & -1.2 \\
\hline & & & \multicolumn{12}{|c|}{5.3} \\
\hline & & \multirow{2}{*}{ std [\%] } & -71.6 & 54.3 & 5.6 & -36.1 & 66.0 & 45.1 & -17.1 & -55.8 & -37.9 & 66.1 & -69.9 & 57.8 \\
\hline & & & \multicolumn{12}{|c|}{-11.8} \\
\hline \multirow{8}{*}{ 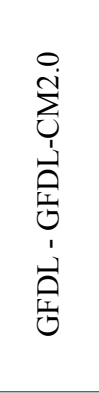 } & \multirow{4}{*}{$T$} & \multirow{2}{*}{ mean $\left[{ }^{\circ} \mathbf{C}\right]$} & 0.8 & 1.6 & 2.1 & 3.4 & 1.8 & 2.4 & 1.9 & 1.2 & 1.7 & 2.4 & 1.3 & 0.7 \\
\hline & & & \multicolumn{12}{|c|}{1.8} \\
\hline & & \multirow{2}{*}{ std [\%] } & 33.4 & 34.9 & -100 & -68.1 & -48.9 & 26.6 & 70.9 & 61.6 & 66.8 & 108.2 & 25.8 & 68.5 \\
\hline & & & \multicolumn{12}{|c|}{19.5} \\
\hline & \multirow{4}{*}{$P$} & \multirow{2}{*}{ mean $[\%]$} & 18.2 & -11.1 & 17.5 & 3.7 & -9.2 & 10.7 & 29.7 & 13.2 & -7.1 & -13.0 & 6.7 & -5.5 \\
\hline & & & \multicolumn{12}{|c|}{4.8} \\
\hline & & \multirow{2}{*}{ std [\%] } & -83.4 & -4.2 & -100 & -96.9 & 48.0 & 27.4 & 38.1 & -61.6 & 31.8 & 45.3 & -70.5 & 57.9 \\
\hline & & & \multicolumn{12}{|c|}{-15.0} \\
\hline \multirow{8}{*}{ 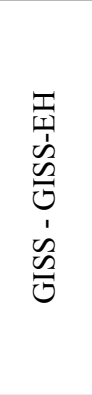 } & \multirow{4}{*}{$T$} & \multirow{2}{*}{ mean $\left[{ }^{\circ} \mathbf{C}\right]$} & 2.6 & 3.6 & 2.4 & 1.8 & 2.8 & 2.0 & 2.2 & 1.7 & 2.1 & 2.0 & 0.9 & 1.9 \\
\hline & & & & & & & & & & & & & & \\
\hline & & 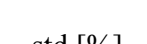 & -34.2 & -100 & -53.7 & 11.0 & 50.7 & 148.9 & 79.2 & -62.6 & -53.7 & 39.1 & -2.8 & -49.7 \\
\hline & & $\operatorname{sic}[1 / 0]$ & & & & & & & & & & & & \\
\hline & & 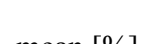 & 28.0 & 19.0 & -2.2 & 19.9 & 1.3 & -26.1 & -3.5 & 16.7 & 25.5 & -10.9 & -2.6 & 11.0 \\
\hline & $D$ & mean $[\%]$ & & & & & & & & & & & & \\
\hline & $\Gamma$ & & 41.6 & -64.1 & 221.3 & -2.8 & 31.7 & 57.8 & 36.7 & 13.2 & 79.1 & 83.6 & -76.1 & 49.3 \\
\hline & & 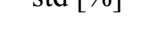 & & & & & & & & & & & & \\
\hline
\end{tabular}

maximum precipitation values - from July, which is the climatologically the wettest month, to June.

The resulting time series generated with the use of the SWGEN model represented spatiotemporally downscaled projections of climate change impact.

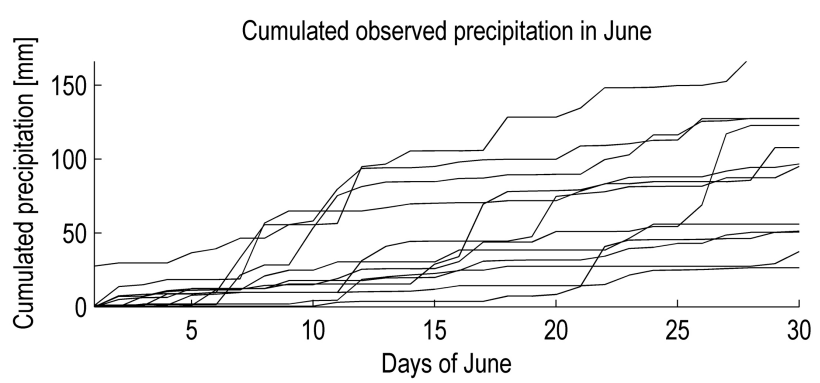

Observed $_{t_{\max }}$ in June

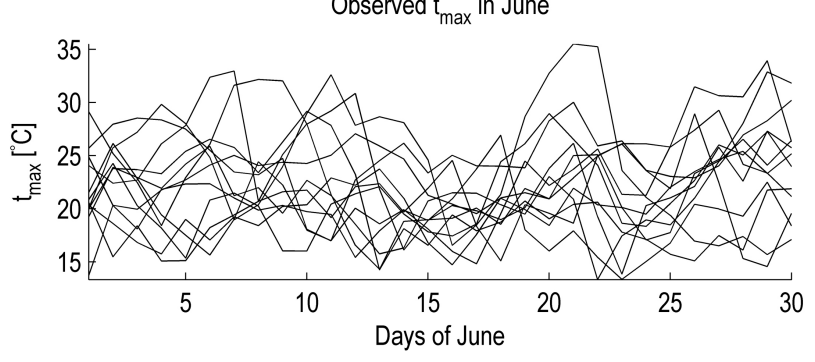

An exemplary set of multiple realizations of daily temperature and precipitation in June 2080 for the Legnica station, according to GFDL projection, and in in comparison to multiple realizations of present conditions, are presented in Fig. 4.

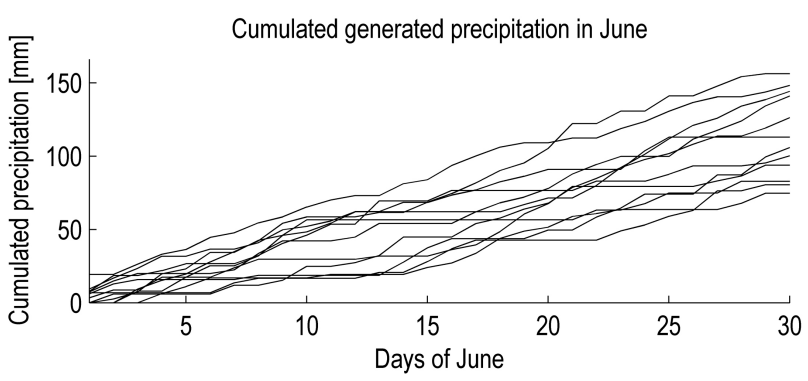

Generated $t_{\max }$ in June

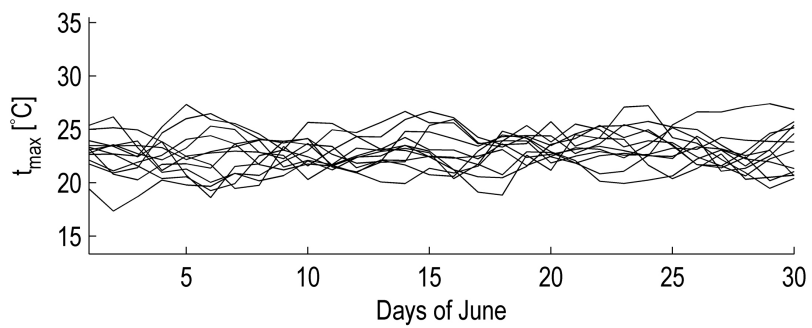

Fig. 4. Multiple realization of present and future (2080) temperature and precipitation time series according to spatiotemporally downscaled GFDL projections with the use of SWGEN model 
Table 3. Assumed changes of climate elements for the time horizon 2080 according to adopted GCM models for the analyzed area

\begin{tabular}{|c|c|c|c|c|c|c|c|c|c|c|c|c|c|c|}
\hline \multirow{2}{*}{$\begin{array}{l}\text { GCM } \\
\text { model }\end{array}$} & \multirow{2}{*}{ par. } & \multirow{2}{*}{ stat. char. } & \multicolumn{12}{|c|}{ Climate projections for 2080} \\
\hline & & & Dec & Jan & Feb & Mar & April & May & June & July & Aug & Sept & Oct & Nov \\
\hline \multirow{8}{*}{ 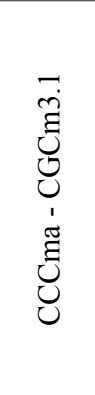 } & \multirow{4}{*}{$T$} & \multirow{2}{*}{ mean $\left[{ }^{\circ} \mathbf{C}\right]$} & 2.5 & 6.2 & 7.8 & 5.2 & 4.8 & 3.2 & 3.3 & 2.7 & 2.3 & 3.9 & 2.3 & 2.9 \\
\hline & & & \multicolumn{12}{|c|}{3.9} \\
\hline & & \multirow{2}{*}{ std [\%] } & 20.6 & -66.8 & -85.2 & 84.1 & 243.6 & -73.8 & -42.4 & -96.8 & 68.3 & 50.4 & -12.1 & -99.3 \\
\hline & & & \multicolumn{12}{|c|}{-43.8} \\
\hline & \multirow{4}{*}{$P$} & \multirow{2}{*}{ mean $[\%]$} & 17.8 & 39.1 & 5.6 & 42.5 & 58.4 & 22.8 & -9.2 & -19.4 & -1.8 & -0.3 & -2.3 & -2.0 \\
\hline & & & \multicolumn{12}{|c|}{8.8} \\
\hline & & \multirow{2}{*}{ std $[\%]$} & -92.2 & 141.6 & 11.7 & -59.8 & 180.2 & 113.1 & -31.7 & -81.0 & -62.1 & 180.6 & -91.3 & 152.8 \\
\hline & & & \multicolumn{12}{|c|}{-22.5} \\
\hline \multirow{8}{*}{ 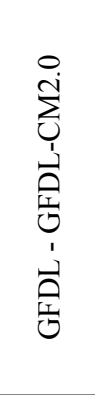 } & \multirow{4}{*}{$T$} & \multirow{2}{*}{ mean $\left[{ }^{\circ} \mathbf{C}\right]$} & 0.6 & 3.0 & 4.5 & 5.6 & 3.1 & 4.2 & 3.1 & 1.6 & 3.1 & 4.3 & 2.6 & 1.8 \\
\hline & & & \multicolumn{12}{|c|}{3.1} \\
\hline & & \multirow{2}{*}{ std [\%] } & 79.7 & 83.8 & -100 & -90.2 & -74.5 & 61.4 & 197.1 & 165.4 & 182.9 & 344.0 & 59.4 & 188.8 \\
\hline & & & \multicolumn{12}{|c|}{43.6} \\
\hline & & $50 / 7$ & 32.4 & -22.9 & 38.8 & 5.6 & -18.4 & 18.1 & 63.9 & 16.8 & -13.0 & -25.6 & 12.7 & -10.3 \\
\hline & $D$ & Hintant $[/ 0]$ & \multicolumn{12}{|c|}{7.8} \\
\hline & & \multirow{2}{*}{ std [\%] } & -97.4 & -8.3 & -100 & -99.9 & 121.8 & 63.7 & 92.7 & -85.7 & 75.2 & 113.7 & -91.6 & 153.2 \\
\hline & & & \multicolumn{12}{|c|}{-28.2} \\
\hline \multirow{8}{*}{ 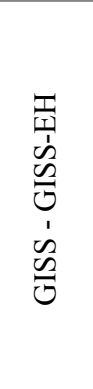 } & \multirow{4}{*}{$T$} & \multirow{2}{*}{ mean $\left[{ }^{\circ} \mathbf{C}\right]$} & 3.9 & 6.6 & 5.0 & 2.7 & 4.9 & 3.4 & 3.6 & 2.5 & 3.7 & 3.5 & 2.0 & 3.9 \\
\hline & & & \multicolumn{12}{|c|}{3.8} \\
\hline & & \multirow{2}{*}{ std [\%] } & -57.3 & -100 & -79.1 & 23.7 & 130.1 & 538.0 & 227.4 & -86.4 & -79.1 & 95.5 & -5.6 & -75.3 \\
\hline & & & & & & & & & & & & & & \\
\hline & & ] & 52.0 & 34.6 & 0.4 & 37.7 & 0.0 & -40.2 & -2.2 & 23.5 & 52.6 & -21.5 & -2.6 & 20.1 \\
\hline & $D$ & Hincain $[/ 0]$ & & & & & & & & & & & & \\
\hline & 1 & 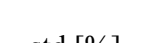 & 102.8 & -87.5 & 972.1 & -5.6 & 74.9 & 152.9 & 88.7 & 28.7 & 226.7 & 243.9 & -94.5 & 125.8 \\
\hline & & & & & & & & & & & & & & \\
\hline
\end{tabular}

3.2. River runoff simulations with MIKE SHE model

The daily discharge data for the Piątnica water gauge station was used in the calibration procedure. The baseline period of 1981-2000 was used for calibration and validation of the period. During the calibration process for the assumed period (1994-2000), satisfactory adjustment coefficients: $\mathrm{R}=0.92[-]$, RMSE $=2.3[\%]$ and Nash-Sutcliffe model efficiency coefficient (1970) $(\mathrm{NSE}=0.82$ [-] were achieved. For the validation period (1981-1987) the obtained results were lower: $\mathrm{R}=0.86[-], \mathrm{RMSE}=4.0[\%]$ and $\mathrm{NSE}=0.67[-]$.

Simulations of values of mean daily discharge $\left[\mathrm{m}^{3} / \mathrm{sec}\right]$ from hydrological model MIKE SHE were performed for the closing water gauge station, Piątnica, in the Kaczawa catchment. The resulting hydrographs were computed using synthetic data from SWGEN, generated for both the baseline year 2000 and for the investigated time horizons, 2040 and 2080, according to three GCM projections of A1B climate change scenario. The number of multi- ple realizations of meteorological conditions was set to 500 . As a result, the total number of realizations of meteorological conditions amounted to 3500: 500 replications for present conditions, 500 replications for both time horizons, repeated for each of the GCM projections. The 3500 synthetic data sets were then repeatedly introduced to hydrological model MIKE SHE and mean daily discharge values were estimated.

\subsection{Hydrological responses to climate change}

Multiple time series of hydrological response, modeled with the use of the MIKE SHE model to a set of realizations of meteorological conditions from the SWGEN model, was used to assess the impact of climate change. The investigation was done for the maximum daily discharge values for an annual period, individual months, and for the selected seasons: from May to October (warm season) and from November to April (cold season). The analyses were done for the Piątnica water gauge station, representing hydrological conditions within the study catchment, Kaczawa. 
Table 4. Mean, Q5 and Q95 for annual and seasonal maximum of daily discharge $\left(\mathrm{m}^{3} / \mathrm{sec}\right)$ simulated for the baseline and for the projection conditions for time horizons 2040 and 2080

\begin{tabular}{|c|c|c|c|c|c|c|c|c|c|c|}
\hline \multirow{2}{*}{ Year } & \multirow{2}{*}{$\begin{array}{c}\text { GCM } \\
\text { model }\end{array}$} & \multicolumn{3}{|c|}{ Year } & \multicolumn{3}{|c|}{ Warm season } & \multicolumn{3}{|c|}{ Cold season } \\
\hline & & Mean & Q5 & Q95 & Mean & Q5 & Q95 & Mean & Q5 & Q95 \\
\hline 2000 & baseline & 67.0 & 35.6 & 119.6 & 58.1 & 18.7 & 119.0 & 48.2 & 23.9 & 84.6 \\
\hline \multirow{3}{*}{2040} & CCCMA & 54.4 & 30.9 & 91.4 & 47.0 & 15.8 & 91.2 & 40.6 & 24.2 & 62.7 \\
\hline & GFDL & 66.1 & 33.8 & 112.2 & 57.4 & 22.1 & 108.5 & 47.0 & 23.8 & 89.7 \\
\hline & GISS & 65.4 & 33.0 & 119.5 & 61.1 & 21.4 & 122.4 & 42.4 & 24.9 & 65.5 \\
\hline \multirow{3}{*}{2080} & CCCMA & 49.1 & 31.3 & 78.7 & 45.0 & 19.7 & 85.4 & 42.3 & 28.3 & 59.3 \\
\hline & GFDL & 56.0 & 31.9 & 92.5 & 54.8 & 23.6 & 101.3 & 44.1 & 24.5 & 70.4 \\
\hline & GISS & 68.0 & 36.2 & 121.7 & 62.4 & 23.2 & 124.5 & 45.4 & 28.7 & 67.3 \\
\hline
\end{tabular}

From each simulation of annual variability of hydrological conditions, a maximum value of daily discharge for the investigated time periods - year, season or individual month - were selected. The resulting ensemble of 500 elements of annual/seasonal/ monthly maximum daily discharge were characterized twofold: by their mean value and a range of quintile values, and by fitting the probability distribution function. Table 4 presents annual and seasonal mean values, Q5 (5\% probability of exceedance) and Q95 (95\% probability of exceedance) obtained for the baseline, and also for the projected changes according to each GCM scenario for time horizons 2040 and 2080 (Tab. 4). The warm season covered the months from May to October, the cold season the months from November to April

On the basis of K-S and Chi-Square tests, lognormal distribution was found as best fitting to the empirical distributions of annual, seasonal, and monthly maximum daily discharge values. The resulting graphs indicate tendencies of maximum discharge values over the analyzed periods, for investigated time horizons with the use of different GCM projections (Fig. 5, 6 and 7). With the analysis of the properties of obtained PDFs, it is possible to identify changes in mean value, coefficient of variation, and return periods of different levels of discharge values.

The obtained graphs for the annual maximum value of daily discharge show that in the long time horizon (2080) this value will decrease according to results from CCMA and GFDL models. The decrease is also observed in standard deviation for the annual maximum daily discharge. In contrast, according to result obtained with the use of the GISS model, the mean value and standard deviation will remain the same (Fig. 5).

For the winter season, the values of maximum daily discharge are likely to slightly decrease for the time horizon 2040. For 2080 this value can increase according to the results from the GISS model and decrease according to results from the GFDL model (Fig. 6). The warm season will undergo some more substantial changes and bigger discrepancies between different GCM scenarios, particularly for 2080. The biggest change is projected for the results from the CCMA model and, according to the projected change, the average values of maximum discharge for warm seasons will decrease (Fig. 7).
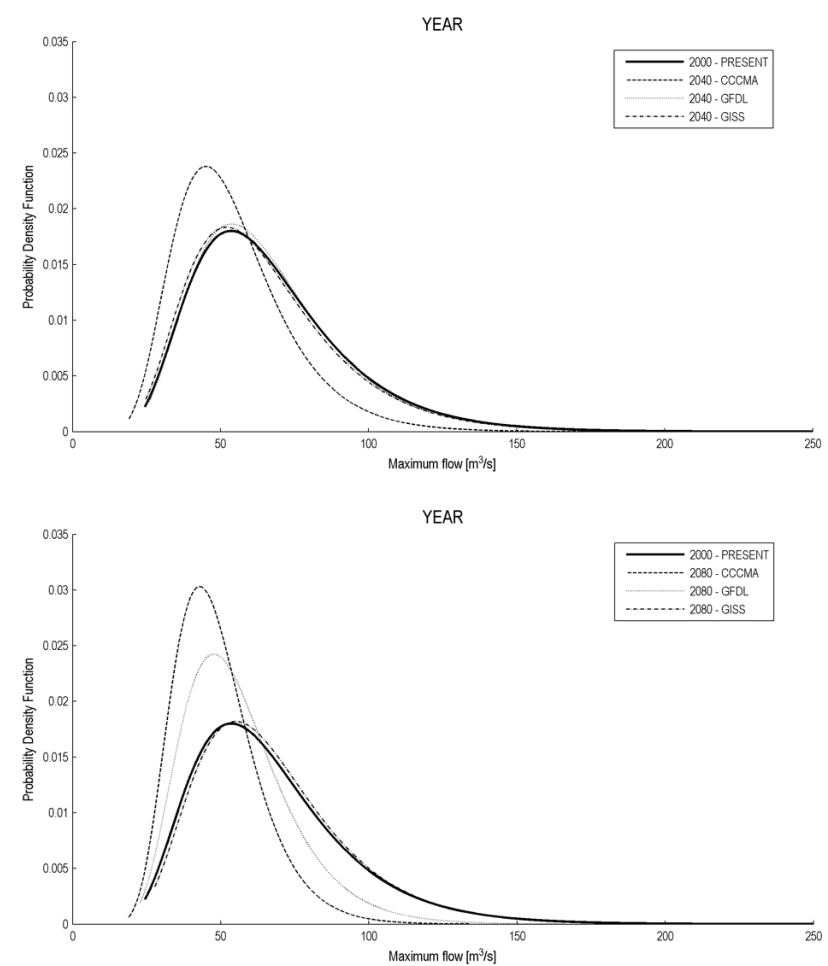

Fig. 5. PDF of annual maximum of daily discharge values at the Piątnica gauge station on the Kaczawa - for the baseline year 2000, for the year 2040 (upper plot) and 2080 (lower plot), according to different GCM projections

The predicted future runoff conditions in the Kaczawa catchment clearly depend on the general development of both temperature and precipitation assumed in the analyzed change in GCM projections of climate change for the A1B emission scenario. 

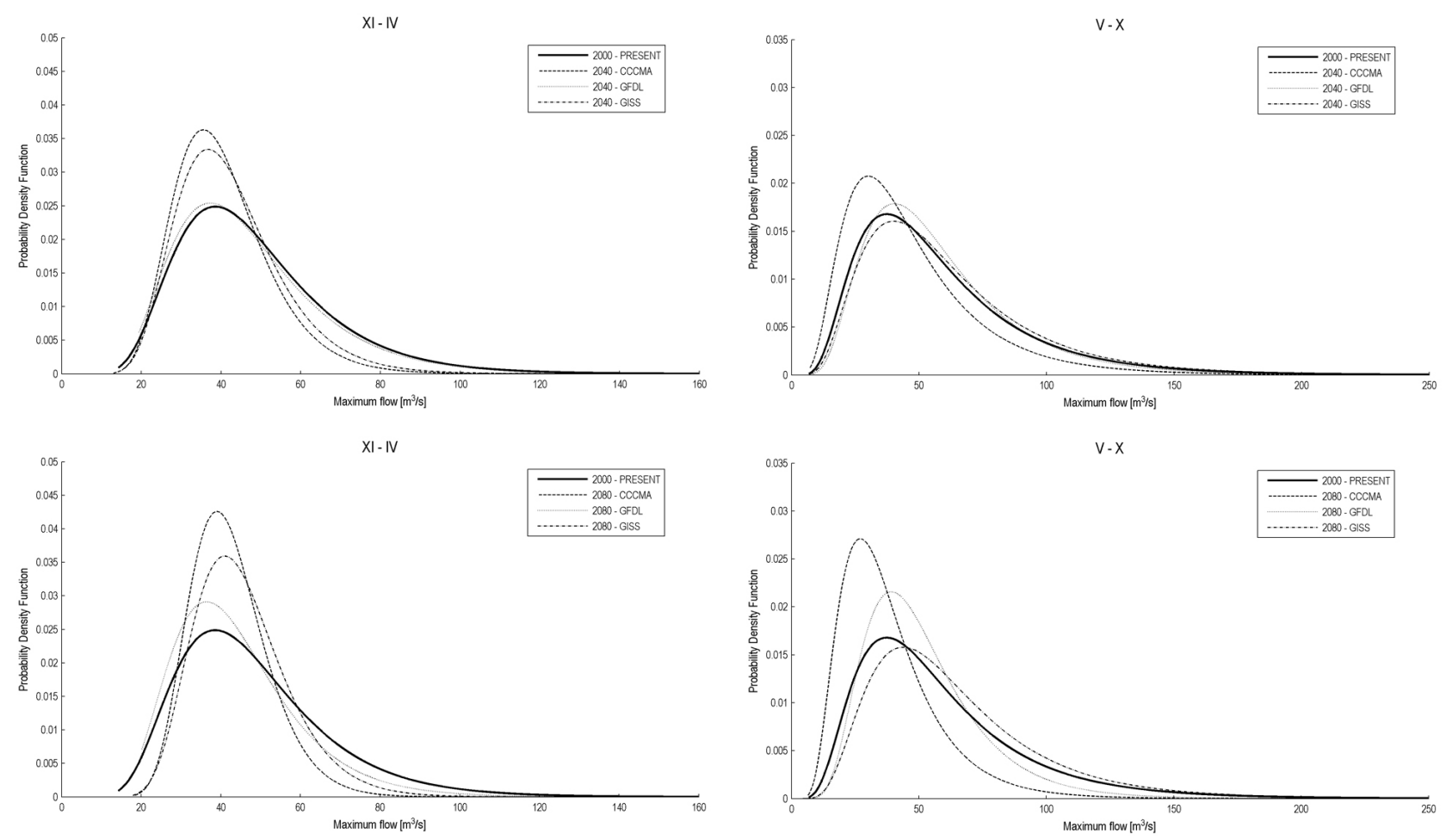

Fig. 6. PDF of maximum seasonal (cold) daily discharge values at the Piątnica gauge station on the Kaczawa river - for the baseline year 2000, for the year 2040 (upper plot) and 2080 (lower plot), according to different GCM projections

The results provided are to present a methodology of processing use of this information in order to infer the hydrological impact of climate change on river runoff.

\section{Conclusions}

The application of the proposed modeling framework facilitates the assessment of the direction and magnitude of changes in water resources due to climate change. Within the framework, the source of uncertainty introduced by the hydrological model was mitigated by applying a distributed, physically based MIKE SHE rainfall-runoff model. The uncertainty associated with the climate change projections were dealt with by using the alternative GCMs, while the uncertainty in the future meteorological condition patterns were addressed by applying spatial weather generator SWGEN to run multiple realizations of future conditions. In the study, the results present the changes in maximum daily discharge, however, the method could provide information on other hydrological characteristics.

The combination of the applied methods - the coupling of the several GCM outputs with the Spatial Weather Generator and the subsequent hydrological simulation of the river runoff - has been demonstra-

Fig. 7. $P D F$ of maximum seasonal (warm) daily discharge values at the Piątnica gauge station on the Kaczawa river - for the baseline year 2000, for the year 2040 (upper plot) and 2080 (lower plot), according to different GCM projections

ted as a useful tool for climate impact studies. The results from Spatial Weather Generator SWGEN successfully replicated the current climatological conditions. This was the foundation for future climate simulations. Climatological data were generated with the temporal and spatial resolution adjusted to the applied hydrological model MIKE SHE. Each replication of the potential realization of climate conditions for the baseline year 2000, year 2040, and year 2080, was introduced to the hydrological model to estimate the series of mean daily discharge values from the Kaczawa catchment at the closing/final gauge. Fitting the obtained discharge ensembles to probability distribution functions allowed for both the inference of the statistical properties, and also the summary of the impact of climate change on the river runoff. Identifying trends and tendencies in changes of discharge characteristics triggered by climate change is required for the optimal management of water resources - this is necessary in the reduction of potential social, economic and environmental losses.

Acknowledgements. The paper presents the results from the first of a series of projects granted by the Polish Ministry of Scientific Research and Information Technology - they focused on the impact of changing climate on streamflow characteristics and 
related processes. These projects aim to develop a set of tools for planning strategies related to climate change adaptation, in order to improve water management practices over a river basin. Funding was provided by Ministry of Science and Higher Education (Grant 600/B/P01/2010/39).

\section{References}

Abbott D., Morton J., Holmes M., 1986, Heat flow measurements on a hydrothermally-active, slow-spreading ridge: the Escanaba Trough, Geophysical Research Letters, 13 (6), 678-680, DOI: 10.1029/GL013i007p00678

Arnell N.W., 2003, Relative effects of multi-decadal climatic variability and changes in the mean and variability of climate due to global warming: future streamflows in Britain, Journal of Hydrology 270 (3-4), 195-213, DOI: 10.1016/S00221694(02)00288-3

Bardossy A., Plate E.J., 1992, Space-time model for daily rainfall using atmospheric circulation patterns, Water Resources Research, 28 (5), 1247-1259, DOI: 10.1029/91WR02589

Barnett T., Malone T., Pennell W., Stammer D., Semtner B., Washington W., 2004, The effects of climate change on water resources in the west: introduction and overview, Climatic Change, 62, 1-11, DOI: 10.1023/B:CLIM.0000013695.21726.b8

Bavay M., Lehning M., Jonas T., Löwe H., 2009, Simulations of future snow cover and discharge in Alpine headwater catchments, Hydrological Processes, 23 (1), 95-108, DOI: 10.1002/hyp.7195

Beersma J.J., Buishand T.A., 2003, Multi-site simulation of daily precipitation and temperature conditional on the atmospheric circulation, Climate Research, 25, 121-133, DOI: 10.3354/ cr025121

Bellone E., Hughes J.P., Guttorp P., 2000, A hidden Markov model for downscaling synoptic atmospheric patterns to precipitation amounts, Climate Research, 15, 1-12

Benestad R.E., Hanssen-Bauer I., Cheng D., 2008, Empiricalstatistical downscaling, World Scientific Publishing Company Pte Ltd., Singapore, 215 pp.

Bergstrom S., Carlsson B., Gardelin M., Lindstrom G., Pettersson A., Rummukainen M., 2001, Climate change impacts on run-off in Sweden - assessments by global climate models, dynamical downscaling and hydrological modeling, Climate Research, 16, 101-112

Black J.N., Bonython C.W., Prescott J.A., 1954, Solar radiation and the duration of sunshine, Quarterly Journal of the Royal Meteorological Society, 80 (344), 231-235, DOI: 10.1002/ qj. 49708034411

Bogardi I., Matyasovszky I., Bardossy A., Duckstein L., 1993, Application of a space-time stochastic model for daily precipitation using atmospheric circulation patterns, Journal of
Geophysical Research: Atmospheres, 98 (D9), 16653-16667, DOI: 10.1029/93JD00919

Brissette F., Khalili M., Leconte R., 2007, Efficient stochastic generation of multi-site synthetic precipitation data, Journal of Hydrology, 345 (3-4), 121-133

Buishand T.A., Brandsma T., 2001, Multisite simulation of daily precipitation and temperature in the Rhine basin by nearest neighbor resampling, Water Resources Research, 37 (11), 2761-2776, DOI: 10.1029/2001WR000291

Burlando P., Rosso R., 2002, Effects of transient climate change on basin hydrology. 1. Precipitation scenarios for the Arno River, central Italy, Hydrological Processes, 16 (6), 11511175, DOI: 10.1002/hyp.1055

Butts M.B., Payne J.T., Kristensen M., Madsen H., 2004, An evaluation of the impact of model structure on hydrological modelling uncertainty for streamflow prediction, Journal of Hydrology, 298 (1-4), 242-266, DOI: 10.1016/j.jhydrol.2004.03.042

Caron A., Leconte R., Brissette F., 2008, An improved stochastic weather generator for hydrological impact studies, Canadian Water Resources Journal, 33 (3), 233-256

Chen J., Brissette F.P., Leconte R., 2011 Uncertainty of downscaling method in quantifying the impact of climate change on hydrology, Journal of Hydrology, 401 (3-4), 190-202, DOI: $10.1016 /$ j.jhydrol.2011.02.020

Chen J., Brissette F.P., Zhang X.C., 2014, A multi-site stochastic weather generator for daily precipitation and temperature, Transactions of the American Society of Agricultural and Biological Engineers, 57 (5), 1375-1397, DOI: 10.13031/ trans.57.10685

Chiew F.H.S., McMahon T.A., 2002, Modeling the impacts of climate change on Australian streamflow, Hydrological Processes, 16 (6), 1235-1245, DOI: 10.1002/hyp.1059

Christensen N.S., Wood A.W., Voisin N., Lettenmaier D.P., Palmer R.N., 2004, Effects of climate change on the hydrology and water resources of the Colorado river basin, Climatic Change, 62 (1-3), 337-63, DOI: 10.1023/B:CLIM.00 $00013684.13621 .1 \mathrm{f}$

DHI, 2007, MIKE SHE User Manual, Vol. 2: Reference Guide, DHI Water \& Environment, DHI Software, http://www. hydroasia.org/jahia/webdav/site/hydroasia/shared/Document_public/Project/Manuals/WRS/MIKE_SHE_ReferenceGuide.pdf (access data 15.01.2015)

Dibike Y.B., Coulibaly P., 2005, Hydrologic impact of climate change in the Saguenay watershed: Comparison of downscaling methods and hydrologic models, Journal of Hydrology, 307 (1-4), 145-163, DOI: 10.1016/j.jhydrol.2004.10.012

Dibike Y.B., Coulibaly P., 2007, Validation of hydrological models for climate scenario simulation: the case of Saguenay watershed in Quebec, Hydrological Processes, 21 (23), 31233135, DOI: 10.1002/hyp.6534 
EEA, 2009, ENSEMBLES: Climate Change and its Impacts: Summary of research and results from the ENSEMBLES project, P. van der Linden, J.F.B. Mitchell (Eds.), Met Office Hadley Centre, FitzRoy Road, Exeter EX1 3PB, UK, 160 pp.

Fatichi S., Ivanov V.Y., Caporali E., 2011, Simulation of future climate scenarios with a weather generator, Advances in Water Resources, 34 (4), 448-467, DOI: 10.1016/j.advwaters.2010.12.013

Feyen L., Vázquez R., Christiaens K., Sels O. Feyen J., 2000, Application of a distributed physically-based hydrological model to a medium size catchment, Hydrology and Earth System Sciences, 4 (1), 47-63, DOI: 10.5194/hess-4-47-2000

Gates W.L., 1985, The use of general circulation models in the analysis of the ecosystem impacts of climatic change, Climatic Change, 7 (3), 267-284, DOI: 10.1007/BF00144171

Graham D.N., Butts M.B., 2005, Flexible, integrated watershed modelling with MIKE SHE, [in:] Watershed Models, V.P. Singh, D.K. Frevert (Eds.), CRC Press, 245-272

Grillakis M.G., Koutroulis A.G., Tsanis I.K., 2011, Climate change impact on the hydrology of Spencer Creek watershed in Southern Ontario, Canada, Journal of Hydrology, 409 (1-2), 1-19, DOI: 10.1016/j.jhydrol.2011.06.018

Hagg W., Shahgedanova M., Mayer C., Lambrecht A., Popovnin V., 2010, A sensitivity study for water availability in the Northern Caucasus based on climate projections, Global and Planetary Change, 73 (3-4), 161-171, DOI: 10.1016/j.gloplacha.2010.05.005

Hughes J.P., Guttorp P., 1994, A class of stochastic models for relating synoptic atmospheric patterns to regional hydrologic phenomena, Water Resources Research, 30 (5), 1535-1546, DOI: 10.1029/93WR02983

Hughes J.P., Guttorp P., Charles S., 1999, A non-homogeneous hidden Markov model for precipitation occurrence, Applied Statistics, 48 (1), 15-30

Huntington T.G., 2006, Evidence for intensification of the global water cycle: Review and synthesis, Journal of Hydrology, 319 (1-4), 83-95, DOI: 10.1016/j.jhydrol.2005.07.003

IPCC, 2007, Climate Change 2007: Synthesis Report, Contribution of Working Groups I, II and III to the Fourth Assessment Report of the Intergovernmental Panel on Climate Change, R.K. Pachauri, A. Reisinger (Eds.), IPCC, Geneva, Switzerland, $104 \mathrm{pp}$.

IPCC-SRES-SPM, 2000, IPCC Special Report: Emissions Scenarios, Summary for Policymakers, Working Group III, IPCC, https://www.ipcc.ch/pdf/special-reports/spm/sres-en. pdf (access data 15.01.2015)

Iwański S., Kuchar L., 2003, Przestrzenne generowanie dobowych danych meteorologicznych, Acta Scientiarum Polonorum - Formatio Circumiectus, 2 (1), 113-121

Jones P.D., Kilsby C.G., Harpham C., Glenis V., Burton A., 2009, Projections of Future Daily Climate for the UK From the
Weather Generator, UK Climate Projections Science Report, University of Newcastle, UK, http://ukclimateprojections. metoffice.gov.uk/media.jsp? mediaid $=87848 \&$ filetype $=$ pdf (access data 15.01.2015)

Khalili M., Leconte R., Brissette F., 2007, Stochastic multi-site generation of daily precipitation data using spatial autocorrelation, Journal of Hydrometeorology, 8 (3), 396-412, DOI: 10.1175/JHM588.1

Khalili M., Brissette F., Leconte R., 2009, Stochastic multi-site generation of daily weather data, Journal of Stochastic Environmental Research and Risk Assessment, 23 (6), 837-849, DOI: 10.1007/s00477-008-0275-x

Kilsby C.G., Jones P.D., Burton A., Ford A.C., Fowler H.J., Harpham C., James P., Smith A., Wilby R.L., 2007a, A daily weather generator for use in climate change studies, Environmental Modelling and Software, 22 (12), 1705-1719, DOI: 10.1016/j.envsoft.2007.02.005

Kilsby C.G., Tellier S.S., Fowler H.J., Howels T.R., 2007b, Hydrological impacts of climate change on the Tejo and Guadiana Rivers, Hydrology and Earth System Sciences, 11 (3), 1175-1189, DOI: 10.5194/hess-11-1175-2007

Kristensen K.J., Jensen S.E., 1975, A model for estimating actual evapotranspiration from potential transpiration, Nordic Hydrology, 6, 70-88

Kuchar L., 2004, Using WGENK to generate synthetic daily weather data for modelling of agricultural processes, Mathematics and Computers in Simulation, 65 (1-2), 69-75, DOI: 10.1016/j.matcom.2003.09.009

Kundzewicz Z.W., Mata L.J., Arnell N.W., Döll P., Kabat P., Jiménez B., Miller K.A., Oki T., Sen Z., Shiklomanov I.A., 2007, Freshwater resources and their management, [in:] Climate Change 2007: Impacts, Adaptation and Vulnerability. Contribution of Working Group II to the Fourth Assessment Report of the Intergovernmental Panel on Climate Change, M.L. Parry, O.F. Canziani, J.P. Palutikof, P.J. van der Linden, C.E. Hanson (Eds.), Cambridge University Press, 173-210

Leander R., Buishand A.T., 2007, Resampling of regional climate model output for the simulation of extreme river flows, Journal of Hydrology, 332 (3-4), 487-496, DOI: 10.1016/j. jhydrol.2006.08.006

Ludwig R., May I., Turcotte R., Vescovi L., Braun M., Cyr J.F., Fortin L.-G., Chaumont D., Biner S., Chartier I., Caya D., Mauser W., 2009, The role of hydrological model complexity and uncertainty in climate change impact assessment, Advances in Geosciences, 21, 63-71, DOI: 10.5194/ adgeo-21-63-2009

Manning L.J., Hall J.W., Fowler H.J., Kilsby C.G., Tebaldi C., 2009, Using probabilistic climate change information from a multimodel ensemble for water resources assessment, Water Resources Research, 45 (11), W11411, DOI: 10.1029/2007WR006674 
Maurer E.P., Levi D.B., Pruitt T., 2010, Contrasting lumped and distributed hydrology models for estimating climate change impacts on California watersheds, Journal of the American Water Resources Association, 46 (5), 1024-1035, DOI: 10.1111/j.1752-1688.2010.00473.x

Menzel A., Burger G., 2002, Climate change scenarios and runoff response in the Mulde catchment (Southern Elbe, Germany), Journal of Hydrology, 267 (1-2), 53-64, DOI: 10.1016/ S0022-1694(02)00139-7

Merritt W.S., Alila Y., Barton M., Taylor B., Cohen S., Neilsen D., 2006, Hydrologic response to scenarios of climate change in sub watersheds of the Okanagan basin, British Columbia, Journal of Hydrology, 326 (1-5), 79-108, DOI: 10.1016/j. jhydrol.2005.10.025

Müller-Wohlfeil D.I., Bürger G., Lahmer W., 2000, Response of a river catchment to climate change: application of expanded downscaling to northern Germany, Climatic Change, 47, 6189, DOI: 10.1016/j.jhydrol.2005.10.025

Nakicenovic N., Alcamo J., de Vries B., Fenhann J., Gaffin S., Gregory K., Grübler A., Jung T.Y., Kram T., La Rovere E.L., Michaelis L., Mori S., Morita T., Pepper W., Pitcher H., Price L., Raihi K., Roehrl A., Rogner H.-H., Sandovski A., Schlesinger M., Shukla P., Smith S., Swart R., van Rooijen S., Victor N., Dadi Z., 2000, Emissions Scenarios; A Special Reports of IPCC Working Group III (SRES). Cambridge University Press, Cambridge, UK

Nash J.E., Sutcliffe J.V., 1970, River flow forecasting through conceptual models part I $-\mathrm{A}$ discussion of principles, Journal of Hydrology, 10 (3), 282-290, DOI: 10.1016/00221694(70)90255-6

Qian B., Gameda S., Jong R., Fallon P., Gornall J., 2010, Comparing scenarios of Canadian daily climate extremes derived using a weather generator, Climate Research, 41 (2), 131149, DOI: $10.3354 /$ cr00845

Richardson C.W., 1985, Weather simulation for crop management models, Transactions of the ASAE, 28 (5), 1602-1606, DOI: $10.13031 / 2013.32484$

Richardson C.W., Wright D.A., 1984, WGEN: A model for generating daily weather variables, US Department of Agriculture, Agricultural Research Service, ARS-8. USDA, Washington, DC

Sahoo G., Ray C., de Carlo E., 2006, Calibration and validation of a physically distributed hydrological model, MIKE SHE, to predict streamflow at high frequency in a flashy mountainous Hawaii stream, Journal of Hydrology, 327 (1-2), 94-109, DOI: 10.1016/j.jhydrol.2005.11.012

Sengupta S., Boyle J.S., 1997, Report PCMDI 40: Comparing GCM Simulations, Ensembles and Model Revisions Using Common Principal Components, Programme for Climate Model Diagnosis and Intercomparison (PCMDI), University of California, Lawrence Livermore National Laboratory
Sharma M., Coulibaly P., Dibike Y.B., 2011, Assessing the need for downscaling RCM data for hydrologic impact study, ASCE Journal of Hydrologic Engineering, 16 (6), 534-539, DOI:10.1061/(ASCE)HE.1943-5584.0000349

Shrestha R.R., Schnorbus M.A., Werner A.T., Berland A.J., 2012, Modelling spatial and temporal variability of hydrologic impacts of climate change in the Fraser River basin, British Columbia, Canada, Hydrological Processes, 26, 1840-1860, DOI: 10.1002/hyp.9283

Sivakumar B., 2011, Global climate change and its impacts on water resources planning and management: assessment and challenges, Stochastic Environmental Research and Risk Assessment, 25 (4), 583-600, DOI: 10.1007/s00477-010-0423-y

Szalińska W., Otop I., Tokarczyk T., 2014, Precipitation extremes during flooding in the Odra River Basin in May-June 2010, Meteorology Hydrology and Water management Research and Operational Applications, 2 (1), 13-20

Sultana Z., Coulibaly P., 2010, Distributed modeling of future changes in hydrological processes of Spencer Creek watershed, Hydrological Processes, 25 (8), 1254-1270, DOI: 10.1002/hyp.7891

Tae-woong K., Hosung A., Gunhui C., Chulsang Y., 2007, Stochastic multi-site generation of daily rainfall occurrence in south Florida, Stochastic Environmental Research and Risk Assessment, 22 (6), 705-717, DOI: 10.1007/s00477-007$0180-8$

Thompson J.R., 2012, Modelling the impacts of climate change on upland catchments in southwest Scotland using MIKE SHE and the UKCP09 probabilistic projections, Hydrology Research, 43 (4), 507-530, DOI: 10.2166/nh.2012.105

Thompson J.R., Green A.J., Kingston D.G., Gosling S.N., 2013, Assessment of uncertainty in river flow projections for the Mekong River using multiple GCMs and hydrological models, Journal of Hydrology, 486, 1-30, DOI: 10.1016/j.jhydrol.2013.01.029

van Roosmalen L., Sonnenborg T.O., Jensen K.H., 2009, Impact of climate and land use change on the hydrology of a largescale agricultural catchment, Water Resources Research, 45 (7), W00A15, DOI: 10.1029/2007WR006760

Vansteenkiste T., Tavakoli M., Ntegeka V., Willems P., De Smedt F., Batelaan O., 2012, Climate change impact on river flows and catchment hydrology: a comparison of two spatially distributed models, Hydrological Processes, 27 (25), 36493662, DOI: 10.1002/hyp.9480

Varis O., Kajander T., Lemmelä R., 2004, Climate and Water: On the search for improved links from climate models to water resources management and vice versa, Climatic Change, 66 (3), 321-344

Wigley T.M.L., 2008, MAGICC/SCENGEN 5.3: User manual (version 2), http://www.cgd.ucar.edu/cas/wigley/magicc/ UserMan5.3.v2.pdf (access data 15.01.2015) 
Wilks D.S., 1992, Adapting stochastic weather generation algorithm for climate change Studies, Climatic Change, 22 (1), 67-84, DOI: 10.1007/BF00143344

Wilks D.S., 1998, Multisite generalization of a daily stochastic precipitation generation model, Journal of Hydrology, 210 (1-4), 178-191, DOI: 10.1016/S0022-1694(98)00186-3

Wilks D.S., 1999, Simultaneous stochastic simulation of daily precipitation, temperature and solar radiation at multiple sites in complex terrain, Agricultural and Forest Meteorology, 96, 85-101, DOI: 1016/S0168-1923(99)00037-4
Wilks D.S., 2010, Use of stochastic weather generator for precipitation downscaling, Climate Change, 1 (6), 898-907, DOI: $10.1002 /$ wcc. 85

Wilks D.S., Wilby R.L., 1999, The weather generation game: a review of stochastic weather models, Progress in Physical Geography, 23, 329-357, DOI: 10.1177/030913339902300302

Wood A.W., Leung L.R., Sridhar V., Lettenmaier D.P., 2004, Hydrologic implications of dynamical and statistical approaches to downscaling climate model outputs, Climatic Change, 62, 189-216, DOI: 10.1023/B:CLIM.0000013685.99609.9e 